\title{
EFFECTS OF COVID-19 ON PHYSICAL ACTIVITY BEHAVIOR AMONG UNIVERSITY STUDENTS: RESULTS OF A HUNGARIAN ONLINE SURVEY
}

\section{WPLYW PANDEMII COVID-19 NA AKTYWNOŚĆ FIZYCZNĄ STUDENTÓW UNIWERSYTETU: WYNIKI WĘGIERSKIEJ ANKIETY ONLINE}

\author{
Pongrác Ács ${ }^{1(\mathrm{~A}, \mathrm{C}, \mathrm{D}, \mathrm{G})}$, Viktória Prémusz ${ }^{1(\mathrm{~A}, \mathrm{D}, \mathrm{E}, \mathrm{F})}$, Kata Morvay-Sey ${ }^{1(\mathrm{~A}, \mathrm{~B}, \mathrm{~F})}$, Ágnes Pálvölgyi ${ }^{1(\mathrm{~A}, \mathrm{~B}, \mathrm{~F})}$,

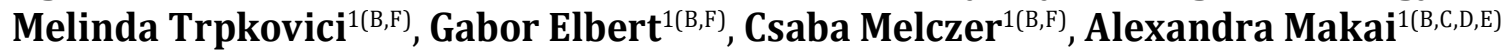

${ }^{1}$ Faculty of Health Sciences, University of Pécs, Hungary

Authors' contribution Wkład autorów: A. Study design/planning zaplanowanie badań B. Data collection/entry zebranie danych C. Data analysis/statistics dane - analiza i statystyki D. Data interpretation interpretacja danych E. Preparation of manuscript przygotowanie artykułu F. Literature analysis/search wyszukiwanie i analiza literatury G. Funds collection zebranie funduszy
Tables: 3

Figures: 1

References: 30

Submitted: $2020 \mathrm{Jul} 2$

Accepted: 2020 Aug 25

\section{Summary}

Background. Due to COVID-19, social isolation and home confinement have changed daily behavior in Hungary since the pandemic hit in early 2020. This study aimed to examine physical activity (PA) patterns among young adults before and during distancing and lockdown safety measures.

Material and methods. We recruited 827 students online across 10 faculties at the University of Pécs during April and May 2020. PA level (IPAQ-SF) and self-rated physical and mental health status were examined. The level of significance was set at $\mathrm{p}<0.05$.

Results. Students' perceived mental health status proved to be worse than perceived physical health, while the percentage of individuals who did not engage in any sports decreased from $37.61 \%$ to $29.26 \%$. Total PA levels and walking times were decreased, while sitting time significantly increased $(\mathrm{p}<0.001)$. A positive correlation was found between perceived physical health and total PA $(R=0.215, p<0.001)$ as well as between perceived mental health and walking $(\mathrm{R}=0.091, \mathrm{p}=0.009)$ and total $\mathrm{PA}(\mathrm{R}=0.106, \mathrm{p}=0.002)$.

Conclusions. We found decreased amounts of PA among university students during the COVID-19 pandemic period, which highlights the need to promote a physically active lifestyle in cases of social restrictions.

Keywords: COVID-19, pandemic, physical activity, sports habits, IPAQ-short form

\section{Streszczenie}

Wprowadzenie. Wirus COVID-19 całkowicie zmienił codzienne zachowania Węgrów u początków 2020 roku ze względu na izolację społeczną i konieczność pozostania w domach. Celem podjętego w niniejszej pracy badania była analiza wzorów aktywności fizycznej (ang. physical activity, PA) wśród młodych dorosłych przed wprowadzeniem obostrzen oraz w trakcie.

Materiał i metody. W badaniu wzięło udział 827 studentów z 10 wydziałów Uniwersytetu w Peczu w okresie od kwietnia do maja 2020 roku. Zbadano poziom aktywności fizycznej (IPAQSF) i własną ocenę ich stanu fizycznego i umysłowego. Poziom istotności wyniósł: p<0,05. Wyniki. Własna ocena zdrowia psychicznego studentów okazała się niższa niż ocena zdrowia fizycznego. Liczba osób, które nie uprawiają żadnego sportu, zmniejszyła się z 37,61\% do $29,26 \%$. Całkowity poziom aktywności fizycznej i czas marszu również uległy zmniejszeniu. Znaczaco wzrósł natomiast czas spoczynku $(\mathrm{p}<0,001)$. Zaobserwowano pozytywna korelacje między własną oceną zdrowia fizycznego a całkowitą aktywnością fizyczną $(R=0,215, p<0,001)$ oraz oceną zdrowia psychicznego a chodzeniem $(\mathrm{R}=0,091, \mathrm{p}=0,009)$ i całkowitą aktywnością fizyczną $(\mathrm{R}=0,106, \mathrm{p}=0,002)$.

Wnioski. Podczas pandemii COVID-19 zaobserwowano obniżony poziom aktywności fizycznej studentów uniwersytetu, co podkreśla istotność promocji aktywnego stylu życia w przypadku restrykcji.

Słowa kluczowe: COVID-19, pandemia, aktywność fizyczna, nawyki sportowe, IPAQ formularz skrócony 


\section{Introduction}

The SARS-CoV-2 virus that causes COVID-19 completely changed the daily behavior of people worldwide in 2020, including young adults. Numerous restrictions due to the pandemic situation led to social isolation and home confinement (HC) and the impact of these measures remains undefined [1]. The COVID-19 pandemic has affected 215 countries including Hungary, infecting more than 21 million people worldwide (as of August 15, 2020). Staying home was prioritized as a safety measure to avoid human-to-human transmission of the virus [2]. During the period of quarantine, one of the acceptable and legitimate reasons for going out was physical activity (PA) [3].

However, the global health crisis has led to high inactivity levels and several studies have shown the negative effects of physical inactivity on health status [4]. The confinement-induced decreases in PA may have a negative effect on people's health, including increased risk of cardiovascular disease [5]. PA does not only have a notable effect in people with chronic diseases, but also impacts healthy young adults.

The inactivity rate among Hungarian university students was found to be $14.72 \%$ among male, and $12.50 \%$ among female students [6]. University students spent more time sitting in front of the computer during the HC period [1]. Regular PA significantly decreases psychological stress and the time spent outdoors in green spaces reduces depression and feelings of anger [7].

Depending on the country, different measures of self-quarantine during the pandemic have been proposed [3]. On March 11, 2020, the Hungarian government declared a state of emergency, and as a result, universities were ordered to suspend in-person classes and switch to online eLearning courses [4]. The daily habits of young adults also changed during HC - this included spending less time being active, going to bed later, sleeping in later and increasing screen time [8]. Limited participation in normal daily activities has meant reduced PA levels and changed daily habits, excluding necessary outdoor activities such as grocery shopping [1].

Having physically active days during lockdown restrictions is an important public health and individual goal. Maintaining regular PA and routinely exercising in a safe home environment is an important strategy for healthy living $[2,9,10]$. Depending on the country, different measures of self-quarantine during COVID-19 have been proposed [11]. On March 11, 2020, the Hungarian government declared a state of emergency during which universities were ordered to suspend in person-classes and switch to online eLearning courses [12].

This study aimed to examine and compare PA patterns among young adults - namely students from different faculties at the University of Pécs, Hungary - before and during COVID-19 restrictions with respect to self-rated mental and physical health status during HC periods.

\section{Material and methods}

\section{Study design}

A cross-sectional, observational cohort study was conducted with consecutive sampling using a selfadministrated questionnaire through a Google online survey form.

\section{Data collection and sample}

Data collection was carried out at the University of Pécs, Hungary. Participants were recruited in the study online using eLearning platforms through the University. We recruited 827 students who filled in the in-depth online survey shared on a Google online platform. The students were recruited from 10 different faculties at the University of Pécs. The data collection started in April 2020 and was completed at the end of May 2020. During the HC period, university students continued their studies using eLearning methods.

The mean age of the students was 25.29 (SD 8.09) and 78.36\% of the respondents were female. Most of the students lived in an urban environment (82.22\%) and $57.68 \%$ of them were not married or cohabitated. Only $11.73 \%$ of the participants had children (Table 1). In regards to sports activities before the HC period, $37.61 \%$ of the respondents not did participate in any sports and during the COVID-19 HC period, this rate decreased to $29.26 \%$. Furthermore, the percentage of students who engaged in sports five or more times a week increased to $8.95-19.23 \%(\mathrm{p}<0.001)$ in the examined period. 
Table 1. Descriptive characteristics of the sample

\begin{tabular}{|c|c|c|c|}
\hline \multicolumn{2}{|c|}{ Characteristics } & Mean or frequency & SD or percent (\%) \\
\hline \multicolumn{2}{|c|}{ Age (years) (mean, SD) } & 25.29 & 8.09 \\
\hline \multirow{2}{*}{$\begin{array}{c}\text { Gender } \\
\text { (frequency, \%) }\end{array}$} & Male & 179 & 21.64 \\
\hline & Female & 648 & 78.36 \\
\hline \multirow{4}{*}{$\begin{array}{l}\text { Place of living } \\
\text { frequency, \%) }\end{array}$} & Capital & 56 & 6.77 \\
\hline & City & 386 & 46.67 \\
\hline & Town & 238 & 28.78 \\
\hline & Village & 147 & 17.78 \\
\hline \multirow{3}{*}{$\begin{array}{l}\text { Marital status } \\
\text { (frequency, \%) }\end{array}$} & Married & 90 & 10.88 \\
\hline & Cohabitated & 260 & 31.44 \\
\hline & Single & 477 & 57.68 \\
\hline \multirow{4}{*}{$\begin{array}{l}\text { Number of children in the } \\
\text { household (frequency, \%) }\end{array}$} & 0.0 & 730 & 88.27 \\
\hline & 1.0 & 33 & 3.99 \\
\hline & 2.0 & 44 & 5.32 \\
\hline & 3.0 & 20 & 2.42 \\
\hline
\end{tabular}

\section{Assessment scales}

Socio-demographic characteristics were obtained through questions regarding age, gender, place of living, marital status and number of children in the household. Furthermore, we examined the number of regular sports activities and self-rated mental and physical health using the 5-point Likert scale (where '1' signifies the worst, and ' 5 ' the best health on the scale).

\section{IPAQ Hungarian short form}

The IPAQ short form questionnaires collect data about vigorous to moderate walking activities and sum the total amount of time spent on PA per week. Through the questionnaire, we collected data on normal daily habits, before COVID-19 and during the HC period. The data were summed by minutes spent on an activity per week (min/week) $[13,14]$.

\section{Mental and physical health}

The self-assessment of health status (referred to as 'subjective health status') can be assessed through a questionnaire. Through the survey, people are able to assess their own health status in a reliable way. Subjective health status is most often assessed by asking respondents to rate their health status on a five-point scale. In our research, participants were asked to endorse the response that best describes how they rate their physical and mental health on a 5-point Likert scale, where a score of 1 means 'very bad' and a score of 5 means 'very good' health [15].

\section{Data privacy and ethical considerations}

In our research, the participants' answers were anonymous and confidential according to Google's privacy policy [16]. Participants were not permitted to provide their names or contact information. Additionally, participants were able to stop study participation and leave the questionnaire at any stage before the submission process; if doing so, their responses would not be saved. Responses were saved only by clicking on the provided "submit" button [1].

The research was conducted according to the Declaration of Helsinki. The survey was approved by the Medical Research Council of Hungary (No. IV/4599-2/2020).

\section{Data analysis}

Descriptive statistics were calculated to determine demographic and PA patterns among university students, with data presented as the mean (standard deviation, SD) or median (interquartile range IQR). Normality of the variables was tested using the Kolmogorov-Smirnov test and according to the results, we used the non- 
parametric Spearman's rank correlation and Kruskal-Wallis tests to examine the relationship between selfrated health status and PA levels, and to examine the difference between PA patterns before and during the pandemic period using Wilcoxon tests. In the examination of gender differences, we used Mann-Whitney U tests. All statistical analyses were performed using SPSS 24.0 software and the p-value was set at 0.05 .

\section{Results}

There were notable differences between self-rated mental and physical health status among students during the pandemic period. Whereas participants did not consider their physical health status to be bad, but as can be seen in Figure 1, they felt their mental health status was significantly worse than their physical health status $(\mathrm{p}<0.001)$ (Figure 1).

mental health $\quad$ physical health

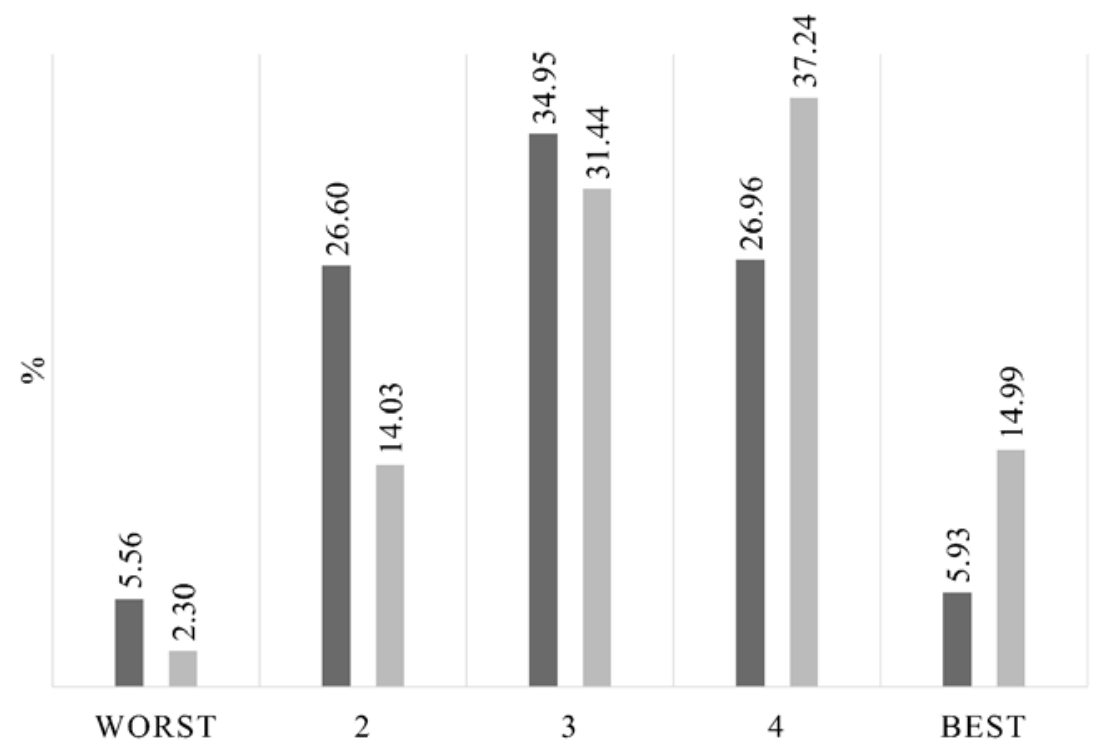

Figure 1. The self-rated mental and physical health status of the university students

Total PA and walking times were found to be significantly decreased, while the average time spent sitting significantly increased during the HC period among the students. The time spent walking decreased by an average of 178.23 (SD 293.78) $\mathrm{min} /$ week and the time spent sitting increased by an average of 85.39 (SD 213.53) $\min /$ day $(\mathrm{p}<0.001)$ (Table 2).

In our research, no significant difference was found between genders in comparing total values of PA before and during COVID-19 ( $\mathrm{p}=0.532, \mathrm{p}=0.700$ respectively). Although before HC, vigorous PA was higher among males than females $(p=0.047)$. 
Table 2. Physical activity (PA) patterns of Hungarian university students using IPAQ-SF before and during the pandemic period in 2020

\begin{tabular}{|c|c|c|c|c|c|c|c|c|c|}
\hline & & Mean & SD & Median & IQR lower & IQR upper & $\begin{array}{c}\text { Decrease } \\
\text { in PA } \\
\text { (Mean } \\
\text { min) } \\
\end{array}$ & $\begin{array}{c}\text { Decrease } \\
\text { in PA (SD } \\
\text { min) }\end{array}$ & $\mathbf{p}$ \\
\hline \multirow{5}{*}{ 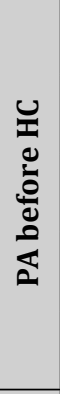 } & $\begin{array}{c}\begin{array}{c}\text { Vigorous min / } \\
\text { week }\end{array} \\
\end{array}$ & 142.85 & 195.67 & 75.00 & 0.00 & 180.00 & & & \\
\hline & $\begin{array}{c}\text { Moderate min / } \\
\text { week }\end{array}$ & 126.74 & 213.67 & 60.00 & 0.00 & 135.00 & & & \\
\hline & $\begin{array}{c}\text { Walking min / } \\
\text { week }\end{array}$ & 342.63 & 303.52 & 250.00 & 140.00 & 420.00 & & & \\
\hline & $\begin{array}{c}\begin{array}{c}\text { Total min } \\
\text { week }\end{array} \\
\end{array}$ & 609.80 & 499.22 & 450.00 & 280.00 & 813.75 & & & \\
\hline & \begin{tabular}{|c|} 
Daily sitting min \\
/day
\end{tabular} & 380.92 & 190.01 & 360.00 & 240.00 & 480.00 & & & \\
\hline \multirow{5}{*}{ 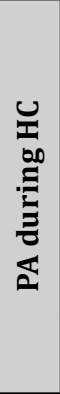 } & \begin{tabular}{|c|}
$\begin{array}{c}\text { Vigorous min / } \\
\text { week }\end{array}$ \\
\end{tabular} & 138.67 & 180.48 & 60.00 & 0.00 & 200.00 & 4.35 & 195.87 & 0.484 \\
\hline & $\begin{array}{c}\begin{array}{c}\text { Moderate min / } \\
\text { week }\end{array} \\
\end{array}$ & 136.72 & 220.66 & 60.00 & 0.00 & 180.00 & -9.89 & 194.79 & 0.170 \\
\hline & $\begin{array}{c}\text { Walking min / } \\
\text { week }\end{array}$ & 162.52 & 237.80 & 60.00 & 20.00 & 180.00 & 178.23 & 293.78 & $<0.001$ \\
\hline & $\begin{array}{c}\begin{array}{c}\text { Total min } / \\
\text { week }\end{array} \\
\end{array}$ & 435.35 & 472.010 & 290.00 & 137.50 & 577.50 & 173.96 & 439.79 & $<0.001$ \\
\hline & \begin{tabular}{|c|}
$\begin{array}{c}\text { Daily sitting min } \\
\text { /day }\end{array}$ \\
\end{tabular} & 466.31 & 234.88 & 480.00 & 300.00 & 600.00 & -85.39 & 213.53 & $<0.001$ \\
\hline
\end{tabular}

In our study, we examined the relationship between PA levels and self-rated mental and physical health. With respect to mental health, a high PA level meant better mental health status, but a significant relationship was shown only in the walking, total PA and sitting time variables.

Physical health showed different results with higher PA levels associated with better physical health, excluding time spent walking $(\mathrm{p}=0.477)$ (Table 3$)$.

Table 3. Relationship between self-rated mental and physical health status and physical activity (PA) patterns

\begin{tabular}{|c|c|c|c|c|c|c|c|c|c|c|c|c|}
\hline \multirow{2}{*}{$\begin{array}{c}\text { Mental SRH / PA } \\
\text { during HC }\end{array}$} & \multicolumn{2}{|c|}{ Worst } & \multicolumn{2}{|c|}{$\mathbf{2}$} & \multicolumn{2}{|c|}{$\mathbf{3}$} & \multicolumn{2}{|c|}{$\mathbf{4}$} & \multicolumn{2}{c|}{ Best } \\
\hline $\begin{array}{c}\text { Vigorous min / } \\
\text { week }\end{array}$ & $\mathbf{9 4 . 0 2}$ & 125.32 & $\mathbf{1 3 6 . 1 9}$ & 163.61 & $\mathbf{1 3 1 . 8 7}$ & 184.68 & $\mathbf{1 5 0 . 8 5}$ & 191.87 & $\mathbf{1 7 7 . 1 9}$ & 210.96 & .235 \\
\hline $\begin{array}{c}\text { Moderate min / } \\
\text { week }\end{array}$ & $\mathbf{8 5 . 9 8}$ & 161.66 & $\mathbf{1 3 8 . 4 4}$ & 219.63 & $\mathbf{1 1 9 . 7 5}$ & 198.55 & $\mathbf{1 5 8 . 2 6}$ & 237.53 & $\mathbf{1 7 8 . 6 7}$ & 296.08 & .123 \\
\hline $\begin{array}{c}\text { Walking min / } \\
\text { week }\end{array}$ & $\mathbf{3 2 . 7 2}$ & 38.60 & $\mathbf{4 1 . 0 5}$ & 41.26 & $\mathbf{4 5 . 0 9}$ & 43.21 & $\mathbf{4 1 . 3 6}$ & 39.38 & $\mathbf{5 8 . 8 8}$ & 62.96 & .037 \\
\hline $\begin{array}{c}\text { Total min / } \\
\text { week }\end{array}$ & $\mathbf{2 7 2 . 9 3}$ & 270.40 & $\mathbf{4 1 8 . 3 8}$ & 461.33 & $\mathbf{4 1 2 . 7 9}$ & 465.08 & $\mathbf{4 6 9 . 8 0}$ & 460.43 & $\mathbf{6 4 3 . 8 5}$ & 664.05 & $\mathbf{. 0 1 0}$ \\
\hline $\begin{array}{c}\text { Daily sitting min } \\
\text { /day }\end{array}$ & $\mathbf{5 6 8 . 4 8}$ & 237.99 & $\mathbf{5 0 4 . 8 0}$ & 221.31 & $\mathbf{4 6 7 . 7 8}$ & 240.48 & $\mathbf{4 2 4 . 2 2}$ & 224.24 & $\mathbf{3 8 0 . 5 1}$ & 246.49 & $<.001$ \\
\hline $\begin{array}{c}\text { Physical SRH / } \\
\text { PA during HC }\end{array}$ & $\mathbf{M e a n}$ & $\mathbf{S D}$ & $\mathbf{M e a n}$ & $\mathbf{S D}$ & $\mathbf{M e a n}$ & $\mathbf{S D}$ & $\mathbf{M e a n}$ & $\mathbf{S D}$ & $\mathbf{M e a n}$ & $\mathbf{S D}$ & $\mathbf{p}$ \\
\hline $\begin{array}{c}\text { Vigorous min / } \\
\text { week }\end{array}$ & $\mathbf{7 4 . 7 4}$ & 157.78 & $\mathbf{5 3 . 6 9}$ & 88.76 & $\mathbf{1 2 9 . 6 2}$ & 187.65 & $\mathbf{1 5 7 . 9 2}$ & 183.05 & $\mathbf{1 9 9 . 5 5}$ & 194.33 & $<.001$ \\
\hline $\begin{array}{c}\text { Moderate min / } \\
\text { week }\end{array}$ & $\mathbf{8 1 . 5 8}$ & 176.01 & $\mathbf{8 7 . 4 1}$ & 156.20 & $\mathbf{1 4 4 . 1 0}$ & 243.71 & $\mathbf{1 3 4 . 7 6}$ & 192.97 & $\mathbf{1 8 0 . 7 3}$ & 277.27 & $\mathbf{. 0 0 4}$ \\
\hline $\begin{array}{c}\text { Walking min / } \\
\text { week }\end{array}$ & $\mathbf{4 8 . 9 5}$ & 47.74 & $\mathbf{4 4 . 6 2}$ & 43.83 & $\mathbf{4 2 . 8 3}$ & 46.59 & $\mathbf{4 1 . 3 7}$ & 38.55 & $\mathbf{4 5 . 9 3}$ & 44.97 & .477 \\
\hline $\begin{array}{c}\text { Total min / } \\
\text { week }\end{array}$ & $\mathbf{2 7 2 . 1 1}$ & 276.52 & $\mathbf{2 8 6 . 5 1}$ & 312.97 & $\mathbf{4 3 8 . 9 6}$ & 546.10 & $\mathbf{4 4 5 . 1 2}$ & 415.34 & $\mathbf{5 6 7 . 8 5}$ & 540.50 & $<.001$ \\
\hline $\begin{array}{c}\text { Daily sitting min } \\
\text { /day }\end{array}$ & $\mathbf{6 8 6 . 3 2}$ & 169.19 & $\mathbf{5 3 7 . 6 7}$ & 241.42 & $\mathbf{4 6 2 . 7 0}$ & 237.44 & $\mathbf{4 6 0 . 3 8}$ & 224.60 & $\mathbf{3 8 8 . 1 5}$ & 220.52 & $<.001$ \\
\hline
\end{tabular}

Notes: SRH - self-rated health, PA - physical activity, HC - home confinement. 
A significant correlation was found between physical health and vigorous $(R=0.276, p<0.001)$ and moderate $(R=0.127, p<0.001)$ PA. Total PA was significantly correlated with physical health $(R=0.215, p<0.001)$. We found a significant positive correlation between mental health and walking time $(R=0.091, p=0.009)$ and total PA $(\mathrm{R}=0.106, \mathrm{p}=0.002)$.

\section{Discussion}

Our study examined and compared physical activity (PA) patterns among young adults, namely students from different faculties at the University of Pécs, Hungary, before and during the restrictions due to COVID-19, as related to self-rated mental and physical health status.

During the global health crisis, Kauxa and Francaux drew attention to the fact that it is still reasonable to practice a sporting activity [10]. Despite the confinement decrees in most countries, affected states have recommended maintaining moderate PA, presumably because it is known in particular to reduce stress and anxiety. However, it is advised to remain alert to "social distancing," and sporting activities must be adapted according to the type of activity [17].

Methods of measuring PA with validated questionnaires is well described $[18,19]$. The International Physical Activity Questionnaire (IPAQ) is one of the most common with the highest comparability due to its widespread international validation [14,20]. Bergier et al. studied levels of total PA and its domains using the IPAQ long questionnaire by gender in Visegrad countries and in the Ukraine. As a common phenomenon found worldwide

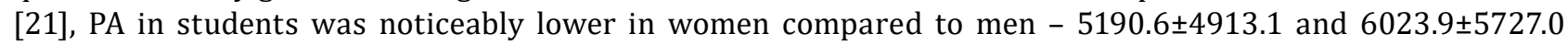
MET (metabolic equivalent) min/week, respectively, overall (across different countries around the world). In the Visegrad countries, sport and leisure time PA was 1470.1 \pm 1921.7 and $1835.2 \pm 2185.6$ [22]. In our research, no significant difference was found between genders when comparing total values of PA before and during COVID-19 HC.

In our sample cohort, there was higher female representation (78.36\%) compared to males. Niźnikowska et al. studied existing differences in levels of PA involving 1169 female students from the Visegrad countries (Czech Republic 24.3\%, Slovakia 21.4\%, Hungary 22.6\% and Poland 31.7\%) where the long version of the IPAQ was used. As influencing factors, BMI, field of study, physical fitness self-assessment and amount of leisure time were considered. The authors found that PA in the domain of recreation and sport and leisure time, $80.7 \%$ of the surveyed female students from the four Visegrad (V4) countries met the World Health Organization's (WHO) recommendations on health-related levels of PA, reporting at least $150 \mathrm{~min} /$ week of moderate, or at least 75 $\mathrm{min} /$ week of vigorous PA lasting for at least 10 minutes [23].

Carvalho et al. also highlighted the importance of the WHO recommendations for the pandemic period. PA can be ranked by intensity, type and duration, and for healthy adults, the WHO suggests 150 minutes of moderate, or 75 minutes of vigorous activity per week. Cavalho et al. suggests that exercise training is not enough to keep healthy. In the case of a pandemic, it is possible to meet the WHO recommendations while performing daily activities such as making breakfast, bathing children, cleaning the floor, etc. - the main goal is to avoid sedentary behavior in instances of HC $[24,25]$. The percentage of respondents who met the WHO recommendations during COVID-19 in our study was $56.83 \%$. This is important because a significant correlation was found between physical health and vigorous $(\mathrm{R}=0.276, \mathrm{p}<0.001)$ and moderate $(\mathrm{R}=0.127, \mathrm{p}<0.001)$ PA. Total PA was significantly correlated with physical health $(\mathrm{R}=0.215, \mathrm{p}<0.001)$.

Rahmati-Ahmadabad et al. recommended moderate activities during the HC period based on indirect evidence and a conservative approach, likely due to the production of oxidants and suppression of the immune system that occurs during high intensity exercise, which may be dangerous (especially, in obese people) and help exacerbate the COVID-19-causing virus [26]. Chen et al. suggested choosing sports with no equipment, little space and that can be practiced at any time using eHealth and exercise videos for maintaining physical function and mental health during the pandemic period [2].

During the pandemic situation, the importance of Infocommunication Technology has been appreciated. In our former study, it was shown that the online community-based eHealth program could provide an appropriate way to promote health and a physically active lifestyle among healthy adults in Hungary. The 12-month eHealth program contained two elements in the form of web-based video tools to increase PA, as well as physical literacy, levels among participants through 10 sessions and web-based educational content. The program can be considered to be a success as a $10.34 \%$ change in PA levels was demonstrated $(\mathrm{p}<0.001)$. Based on our results, the community-based eHealth program can be a popular and effective way to motivate healthy adults to follow a healthy and physically active lifestyle [27]. 
Jurak et al. summarized the PA recommendations for Slovenian people during the pandemic and periods of quarantine. The recommendations' bottom line is to stay active and harmonize regular sport activity with family activities, decrease screen time, hydrate and achieve good sleep quality as these are all essential for good mental health status, comparable to a physically active lifestyle [7].

In our study, mental health was found to be significantly lower $(p<0.001)$ than physical health during COVID-19. Maintaining or improving PA habits during challenging times such as a pandemic is very important. PA can interact with psychological burdens such as worrying about the health of relatives and your own health, changing living conditions, modified educational methods and economic burdens. The positive effects of PA and the negative consequences of a sedentary lifestyle on mental health are well proven in both general and specific populations [28-30]. We also found a significant positive correlation between mental health and walking time $(\mathrm{R}=0.091, \mathrm{p}=0.009)$ and total PA $(\mathrm{R}=0.106, \mathrm{p}=0.002)$. The negative effects of a sedentary lifestyle were also shown in our research. Respondents with the best mental and sexual reproductive health spent significantly $(\mathrm{p}<0.001)$ lower times $(380.51 \pm 246.49 \mathrm{~min} /$ day) sitting compared to respondents with the worst mental and sexual reproductive health (568.48 $\pm 237.99 \mathrm{~min} /$ day).

Green open spaces are valuable resources for physical activities and have the potential to reduce chronic illness and improve health. In our research cohort, $17.78 \%$ of participants marked capital, city or town as place of living. It can be hypothesized that this urban population that lives in areas with less green places is engaging in less outdoor activities, and has to pay closer attention to safety measures due to the high density areas in which they live, which could further reduce the amount of physical activities that they perform. It could be seen that during HC, total and walking activity were reduced by $173.94 \pm 39.79$ and $178.23 \pm 293.78 \mathrm{~min} /$ week, respectively $(\mathrm{p}<0.001)$. However, during the period of quarantine, one of the legitimate reasons for going out was for health-enhancing PA. This could perhaps be one of the reasons why amounts of moderate PA did not decrease, but rather increased by $9.89 \pm 194.79$ minutes weekly.

The period of university studies is often the final stage of formal education and therefore, the last opportunity to provide and monitor a large-scale of PA programs and improve physical literacy among young adults, which can lead to further improvements in physical and mental health. The main take-home message for university students who quit doing sports during HC and also for students who started to engage in sports in this period comes from Lakicevic et al.: "stay fit, don't quit!" [11].

\section{Strengths of the study}

Most of the published articles related to PA and COVID-19 mainly rely on previously established evidence and general recommendations. To the best of our knowledge this study by our research group is the first one which extensively investigated, with survey methods, the PA patterns of university students during COVID-19. The study achieved a relatively large sample size and reached a wide range of students from different fields of study across 10 faculties at the university.

\section{Limitations}

The limitations of the study include the sample's non-representative nature. To avoid potential confounders, participants were carefully selected, making the study population modest. Objective measurements of PA patterns cannot be conducted by all individuals and complete medical records were also missing for a portion of patients.

For more impressive results on the effects of PA on physical and mental health, a detailed objective assessment of PA including a larger number of participants, as well as detailed examinations of physical and mental health using validated questionnaires are needed in a well-powered randomized controlled prospective study. However, for good reason, the authors hope that a similar global pandemic situation will not occur to repeat the study.

\section{Conclusions}

We found decreased levels of PA among university students during the COVID-19 pandemic period, which highlights a need to promote a physically active lifestyle in the case of pandemic-associated restrictions because higher activity levels are associated with better perceived mental and physical health status among young people. 


\section{Disclosures and acknowledgements}

The publication costs were partially funded by the Human Resource Development Operational Program, grant No.: HRDOP-3.6.2-16-2017-00003, Cooperative Research Network in Economy of Sport, Recreation and Health. The authors declare that the study design, along with the collection, management, analysis and interpretation of data, as well as writing of the manuscript are independent of Human Resource Development Operational Program. The authors declare that they have no competing interests.

\section{References:}

1. Ammar A, Brach M, Trabelsi K, Chtourou H, Boukhris O, Masmoudi L, et al. Effects of COVID-19 home confinement on eating behaviour and physical activity: results of the ECLB-COVID19 International Online Survey. Nutrients. 2020; 12(6): 1583.

2. Chen P, Mao L, Nassis GP, Harmer P, Ainsworth BE, Li F. Coronavirus disease (COVID-19): the need to maintain regular physical activity while taking precautions. Journal of Sport and Health Science. 2020; 9(2): 103-104. https://doi.org/10.1016/j.jshs.2020.02.001

3. Goethals L, Barth N, Guyot J, Hupin D, Celarier T, Bongue B. Impact of home quarantine on physical activity among older adults living at home during the COVID-19 pandemic: qualitative interview study. JMIR Aging. 2020; 3(1): e19007. https://doi.org/10.2196/19007

4. Apor P, Babai L. Physical activity diminishes aging-related decline of physical and cognitive performance. Orvosi Hetilap. 2014; 155(21): 817-821. https://doi.org/10.1556/0H.2014.29838

5. Peçanha T, Goessler KF, Roschel H, Gualano B. Social isolation during the COVID-19 pandemic can increase physical inactivity and the global burden of cardiovascular disease. American Journal of Physiology, Heart and Circulatory Physiology. 2020; 318(6): H1441-h1446. https://doi.org/10.1152/ajpheart.00268.2020

6. Ács P, Prémusz V, Makai A, Junger J, Bergier J. Physical activity of university students according to IPAQ long questionnaires results. In: Potočníková J, Bakalár P., editors [Recreational sports, health, quality of life]. 4th edition. Kosice: Univerzita Pavla Jozefa Safárika v Kosiciach; 2018. p. $22-22$ (in Slovak).

7. Jurak G, Morrison SA, Leskošek B, Kovač M, Hadžić V, Vodičar J, et al. Physical activity recommendations during the coronavirus disease-2019 virus outbreak. Journal of Sport and Health Science. 2020; 9(4): 325327. https://doi.org/10.1016/j.jshs.2020.05.003

8. Guan H, Okely AD, Aguilar-Farias N, Del Pozo Cruz B, Draper CE, El Hamdouchi A, et al. Promoting healthy movement behaviours among children during the COVID-19 pandemic. Lancet Child Adolesc Health. 2020; 4(6): 416-418. https://doi.org/10.1016/S2352-4642(20)30131-0

9. Chen P, Mao L, Nassis GP, Harmer P, Ainsworth BE, Li F. Returning Chinese school-aged children and adolescents to physical activity in the wake of COVID-19: actions and precautions. Journal of Sport and Health Science. 2020; 9(4): 322-324.

10. Kaux JF, Francaux M. Physical activity during the Covid-19 pandemic. Science \& Sports. 2020; 35(3): 117-118. https://doi.org/10.1016/j.scispo.2020.05.001

11. Lakicevic N, Moro T, Paoli A, Roklicer R, Trivic T, Cassar S, et al. Stay fit, don't quit: geriatric exercise prescription in COVID-19 pandemic. Aging Clinical and Experimental Research. 2020; 32: 1209-1210. https://doi.org/10.1007/s40520-020-01588-y

12. www.koronavirus.gov.hu [Internet]. Budapest: Cabinet Office of the Prime Minister; 2020 [cited 2020 March 20.]. Available from: www.koronavirus.gov.hu (in Hungarian).

13. Ainsworth BE, Haskell WL, Herrmann SD, Meckes N, Bassett DR Jr, Tudor-Locke C, et al. 2011 Compendium of Physical Activities: a second update of codes and MET values. Med Sci Sports Exerc. 2011, 43(8): 1575-1581. https://doi.org/10.1249/MSS.0b013e31821ece12

14. Craig CL, Marshall AL, Sjostrom M, Bauman AE, Booth ML, Ainsworth BE, et al. International physical activity questionnaire: 12-country reliability and validity. Medicine and Science in Sports and Exercise. 2003; 35(8): 1381-1395. https://doi.org/10.1249/01.MSS.0000078924.61453.FB

15. Idler EL, Benyamini Y. Self-rated health and mortality: a review of twenty-seven community studies. Journal of Health and Social Behavior. 1997; 38(1): 21-37. https://doi.org/10.2307/2955359

16. www.google.com [Internet]. Mountain View: Google LLC; 2020. Privacy policy [cited 2020 March 20]. Available from: https://policies.google.com/privacy?hl=en

17. Toresdahl BG, Asif IM. Coronavirus disease 2019 (COVID-19): considerations for the competitive athlete. Sports Health. 2020; 12(3): 221-224. https://doi.org/10.1177/1941738120918876 
18. Ács P, Betlehem J, Oláh A, Bergier B, Morvay-Sey K, Makai A, et al. Cross-cultural adaptation and validation of the Global Physical Activity Questionnaire among healthy Hungarian adults. BMC Public Health. 2020; 20(Suppl. 1): 1056. https://doi.org/10.1186/s12889-020-08477-z

19. Ács P, Betlehem J, Oláh A, Bergier J, Melczer C, Prémusz V, et al. Measurement of public health benefits of physical activity: validity and reliability study of the International Physical Activity Questionnaire in Hungary. BMC Public Health. 2020; 20(Suppl. 1): 1198. https://doi.org/10.1186/s12889-020-08508-9

20. Bauman A, Ainsworth BE, Sallis JF, Hagstromer M, Craig CL, Bull FC, et al. The descriptive epidemiology of sitting a 20-country comparison using the International Physical Activity Questionnaire (IPAQ). American Journal of Preventive Medicine. 2011; 41(2): 228-235. https://doi.org/10.1016/j.amepre.2011.05.003

21. El Ansari W, Berg-Beckhoff G. Country and gender-specific achievement of healthy nutrition and physical activity guidelines: latent class analysis of 6266 university students in Egypt, Libya, and Palestine. Nutrients. 2017; 9(7). https://doi.org/10.3390/nu9070738

22. Bergier J, Tsos A, Popovych D, Bergier B, Niznikowska E, Acs P, et al. Level of and factors determining physical activity in students in Ukraine and the Visegrad countries. International Journal of Environmental Research and Public Health. 2018; 15(8): 12. https://doi.org/10.3390/ijerph15081738

23. Niźnikowska E, Bergier J, Bergier B, Acs P, Junger J, Salonna F. Factors influencing level of physical activity among female students from the Visegrad countries. Health Prob Civil. 2019; 13(1): 19-29. https://doi.org/10.5114/hpc.2018.80225

24. Carvalho VO, Gois CO. COVID-19 pandemic and home-based physical activity. The Journal of Allergy and Clinical Immunology in Practice. Forthcoming 2020. https://doi.org/10.1016/j.jaip.2020.05.018

25. WHO. Global action plan on physical activity 2018-2030: more active people for a healthier world. Geneva: World Health Organization; 2018.

26. Rahmati-Ahmadabad S, Hosseini F. Exercise against SARS-CoV-2 (COVID-19): does workout intensity matter? (A mini review of some indirect evidence related to obesity). Obes Med. 2020; 19: 100245. https://doi.org/10.1016/j.obmed.2020.100245

27. Makai A, Cseh AM, Breitenbach Z, Füge K, Járomi M, Prémusz V, et al. A web-based intervention to promote and increase physical activity level of Hungarian healthy adults. In: Prága FS., editor. Abstract book for the ISBNPA 2019 Annual Meeting in Prague. Prague: International Society of Behavioral Nutrition and Physical Activity; 2019. p. 1163-1163.

28. Prémusz V, Makai A, Gács B, Lászikné Nagy Á, Bánkyné Perjés B, Ács P, et al. Preliminary study on pretreatment physical activity and quality of life in infertility. EQOL. 2019; 11(2): 5-17.

29. Makai A, Prémusz V, Lampek K, Ács P, Simon-Ugron Á, Figler M. Sitting time and sport participation of the employed population in Hungary and Europe. Studia Universitatis Babes-Bolyai Educatio Artis Gymnasticae. 2018; LVIII(2): 11-22. https://doi.org/10.24193/subbeag.63(2).10

30. Haskell WL, Lee IM, Pate RR, Powell KE, Blair SN, Franklin BA, et al. Physical activity and public health: updated recommendation for adults from the American College of Sports Medicine and the American Heart Association. Medicine and Science in Sports and Exercise. 2007; 39(8): 1423-1434.

https://doi.org/10.1249/mss.0b013e3180616b27 